\title{
SUBJECTS OF PUBLIC ADMINISTRATION: REFORMING THE CONCEPT IN UKRAINE
}

\author{
Kateryna Holovko', Svitlana Levchenko², Oleg Dubinskiy³
}

\begin{abstract}
The article is devoted to the identification of subjects, which, under the conditions of administrative and legal reform and changes of the guidelines in the relations between the state and the citizen, carry out public administration. Emphasis is placed on the sphere of relations that cover the essence of public administration. It is proved that the effectiveness of administrative law through the lens of governance is doubtful and does not fully meet the requirements of the development of public relations. Therefore, it is necessary to return to the educational ideas of the functioning of the state and its interaction with citizens, which has a manifestation in public, not state; in administration, not government. The authors substantiate that public administration is the activity of public authorities, which manifests itself in a concerted influence on specific public relations by means of specific methods, tools, forms and aims to secure public interests. The relation between the concepts of "subject of public administration" and "public management" is investigated. The proposals of the leading Ukrainian administrative scientists regarding the essence of the category of "public management" are analyzed and the reasons for the dualism of approaches to its definition in the Ukrainian administrative and legal doctrine are revealed. In addition, the subjects of public administration are classified according to their competence, scope, functions, and objectives of public administration. The subject of the research is the subjects of public administration and their functions in administrative law. The purpose is a study of the institutional constituent of public administration and defining changes experienced by governing entities as a result of reformatting the concept of relations between the state and society in Ukraine. Methodological basis of the research is a set of methods and techniques of scientific knowledge. The methodological construction is based on a systemic analysis that determined its directions. The systemic approach in some issues was supplemented by the axiological (ideological) approach. Empirical methods such as observation, description, comparison, inductive generalization were used to identify tendencies of reforming the system of subjects of administrative law of Ukraine. Logical-semantic method was used for formulation and in-depth study of the conceptual apparatus. The dialectical method of cognition made it possible to investigate the problems associated with the definition of the concept of "public administration". The application of methods of modeling, analysis, synthesis, generalization and analogy made it possible to formulate the conclusions of the study. Conclusions of the research correlate with the delineation of the institutional component of public administration in Ukraine. The authors have made qualitative and quantitative changes concerning the updating of the subjects of administrative law. At the same time, in the conditions of development of Ukraine as a democratic and rule-of-law state, all reform initiatives should be systematic and consistent with each other, therefore, during the study, the features that characterize the subject of public administration are highlighted. The scientific and analytical monitoring of the state of the introduced changes and the consequences of the implemented administrative reform measures for the classification of the subjects of public administration was carried out. Practical implications. The results of the research will help to understand the basic aspects of the content of public administration better and can be used in the research field in order to further study the issue of transformational changes that governing subjects under the background of actualization of trends of democratization and humanization of administrative processes.
\end{abstract}

Key words: democratization, humanization, human-centric concept, public administration, subject of public administration, public administration, public management.

JEL Classification: H76, H83

\footnotetext{
Corresponding author:

${ }^{1}$ Black Sea Research Institute of Economy and Innovation, Ukraine.

E-mail: k.v.mozharovska@gmail.com

${ }^{2}$ Black Sea Research Institute of Economy and Innovation, Ukraine.

E-mail: lightstarpro@ukr.net

ORCID: https://orcid.org/0000-0002-3386-5962

${ }^{3}$ Admiral Makarov National University of Shipbuilding, Ukraine.

E-mail: dubinskiy_oleg@ukr.net
} 


\section{Introduction}

The development of the Ukrainian nation should be a priority for any governing body, it is with no specific justification. Instead, the institutional and legal mechanisms for ensuring the proper influence of the state on public relations are characterized by casuistic tendencies of discrepancy between the existing state of society's needs and the requirements which they place on the governing entity, the model of the system of public administration entities that should be implemented in Ukraine. The negative signs of governance are, first of all, the lack of a clear algorithm for holding subjects of public administration accountable, defining mechanisms for their interaction with civil society institutions. Public administration cannot develop and function in isolation from the problems of today and the consequences of social development. Therefore, both the development of a long-term concept of sustainable development of public administration institutional support and the constant monitoring of existing and emerging problems in the said field seem urgent.

Despite the fact that a number of administrative theorists and practitioners have devoted their attention to the study of the nature and content of the problems of the system of public administration in Ukraine: Averianov V.B., Bevzenko V.M., Bytiak Yu.P., Bondarenko H.P., Golosnichenko I.P., Kivalov S.V., Kolomoiets T.O., Kurinnyi Ye.V., Melnyk R.S., Stetsenko S.H. and others, at the present stage, many aspects are left unaddressed by scientific knowledge. Therefore, the relevance of the issue of research on the changes experienced by the governing entities as a result of reformatting the concept of relations between the state and society in Ukraine, the theoretical and practical significance of the chosen topic are not in doubt.

The purpose is a study of the institutional constituent of public administration and defining changes experienced by governing entities as a result of reformatting the concept of relations between the state and society in Ukraine.

Methodological basis of the research is a set of methods and techniques of scientific knowledge. The methodological construction is based on a systemic analysis that determined its directions. The systemic approach in some issues was supplemented by the axiological (ideological) approach. Empirical methods such as observation, description, comparison, inductive generalization were used to identify tendencies of reforming the system of subjects of administrative law of Ukraine. Logical-semantic method was used for formulation and in-depth study of the conceptual apparatus. The dialectical method of cognition made it possible to investigate the problems associated with the definition of the concept of "public administration". The application of methods of modeling, analysis, synthesis, generalization and analogy made it possible to formulate the conclusions of the study.

\section{Public administration as a qualitative indicator of the development of power-subordination relations}

The area of public administration essentially reflects a qualitative approach to public governance. Administration (from the Latin "administratio" "service", "assistance", "governance") is an activity that consistsin directing and managing certain socialrelations. By focusing on the essence of administration, I.P. Yakovliev states that in the theory and practice of administration it is used to describe: governance and its mechanism, implementation of administrative orders in the judicial branch of state power, executive and administrative activity of the state, science of public administration, processes of payment of obligatory payments, etc. (2015) Along with this, S.I. Chernov and S.O. Paiduchenko's define administration as the prerogative of executive authorities or an official (civil servant) (2014). That is, administration is regarded as an analogue of governance. However, governance is a deliberate influence precisely on governance objects, using methods that imply the subordination of these objects to government influence by the subject of governance (Kniaziev \& Bakumenko, 2002). Moreover, understanding administration as a synonym for governance has no logical basis, since replacing one term with another does not change the nature of the phenomenon that is characterized.

Turning to the definition of "administration" in its original meaning, let us pay attention to itsinterpretation as activities of "service" and "assistance". Such interpretation is characteristic of the human-centric approach in administrative law. The advantage of a democratic model of state-citizen relations is, first of all, reflected in the longterm perspective, which is the flexibility and elasticity provided by effective feedback (Bila-Tiunova, BilousOsin, Kozachuk, Vasylkivska, 2019).

It should be noted that progressive thoughts on the appointment of administrative law are traced back to the works of A.I. Yelistratov, who found that administrative law best protects the individual from excessive state intervention, incompatible with the conditions of his/ her free development (1917). At the present stage, the aforementioned thesis is undeniable, but the process of its transfer into legal reality and scientific circulation is still ongoing. At the present stage, the aforementioned thesis is undeniable, but the process of its transfer into legal reality and scientific circulation is still ongoing. In this case, as it is indicated by R.S. Melnyk and V.M. Bevzenko, only since the declaration of Ukraine's independence, the enshrining in its Basic Law of the provision that a person, his/her life and health, honor and dignity, inviolability and security are recognized as of the highest social value, the process of reforming the relations between the population and state power began, which must end in civil society development. 
The solution to this problem can only be achieved by reviewing the role of state power in society (2014).

Re-evaluation of the priority of state interests is a reflecting of a new approach to the way the state's organizational influence on public relations. Public administration is characterized by securing the interests of the person with the emphasis on the individual as the main subject of administrative and legal relations (Pyrozhkova, 2017). In addition, human-centrism, as a new concept of administrative law, is to ensure and adhere to the principle of rule of law (power of law) in the public-legal sphere, to ensure the focus of administrative law on the priority of the rights of individuals and legal entities, to ensure the observance of constitutional principles in all areas of social life without exception (Yarovska, 2016).

Thus, the effectiveness of administrative law through the lens of governance is dubious and does not meet the requirements of the development of public relations. Therefore, it is necessary to return to the educational ideas of the functioning of the state and its interaction with citizens.

Modern administrative law has to operate with the concept of "administration", which reflects the influence of the state represented by the authorized bodies on public relations in a way that is, first and foremost, effective for the individual. If necessary, the state should govern, otherwise it should assist, but in any case, such activity should be carried out in order to serve the people. For these reasons, the term "administration" fully reflects the state of qualitative development of the functioning of the state and the way it organizes influence on public relations.

With regard to publicity, one of the main features of administration is the following. The difference between "public" and "state" lies in qualitative and quantitative indicators. In terms of quantitative differences, they relate to etymological comparisons of a relatively larger amount of publicity. Subjects of public authority, in addition to state authorities, authorities of the Autonomous Republic of Crimea, include bodies of local self-government, organizations with delegated powers, and possibly other public authorities. Thus, the category of "public service" has become widely used in domestic administrative science. The need to rethink the role of public authority ensured the emergence of new social roles for citizens, enhancing their jurisprudence and shaping their legal culture, on the one hand (Gestel, Kuiper, Hendrikx, 2019), and, on the other hand, the need for well-being for people (Torres, Barreto, Maggia, Gibaja, 2019).

The voluminous prevalence of "public service" is confirmed by the provisions of the Code of Administrative Proceedings of Ukraine. According to paragraph 15 of part 1 of the Article 3 of the Code of Administrative Proceedings of Ukraine, public service means the activity in the state political positions, professional activity of judges, prosecutors, military service, alternative (non-military) service, diplomatic service, other civil service, service in the authorities of the Autonomous Republic of Crimea, local authorities. That is, the concept of "public" is broader than the concept of "state".

It is rightly nored by I.P. Yakovliev that the main purpose of the public is public interest, guaranteeing the common good of civil society, its stable development, combined with ensuring and maintaining effective institutions of self-regulation. Secondly, in the reference literature, the term "public" further states the need for informational interaction of public authorities with society, which has become one of the qualitative features of administration (2016).

Bondarenko K.V. differentiates the concepts of "public administration" and "public givernance" according to the criteria of subject composition, implementation, essence, nature, characteristics (2018). Inherently, these criteria reflect the qualitative and quantitative changes that the "concept of the state" underwent when transformed into the "concept of the public".

Thus, public administration refers to the activity of public authorities, which has a manifestation in the concerted influence on specific public relations by means of specific methods, tools, forms and aimed at securing public interests.

\section{Concerning the essence of the concept of "subject of public administration"}

Concerning a particular type of public administration, public relations emerge, which are characterized by a set of specific characteristics. At the same time, participants in relations, which arise in the process of public administration, can be classified as those who exert a concerted influence on specific public relations by means of specific methods, tools, forms and aiming to secure public interests and those who fall under the influence of such a concerted influence. This statement correlates with the generally accepted approach to the relation between the terms of "subject of legal relations" and "legal subject". A subject exercising a concerted influence and having the relevant powers is inherently a subject of public administration.

In general, the doctrine of administrative law uses the following approaches to the essence of the concept of "subject of public administration". Firstly, the practice of using the concepts of "public administration" and "subject of public administration" as synonyms is widely known (Halunko, Dikhtiievskyi, Kuzmenko, Stetsenko et al., 2018). From a functional point of view, this is true, since the subject of public administration is one who is authorized to carry out such activity. Accordingly, the group of these subjects is determined to be designated as "public management".

Two approaches can be applied to the definition of public administration in the European law: narrow and 
wide. The first approach is to define "public management" as"regional authorities, local and otherpublic authorities", "central governments" and "public service". At the same time, public authorities are institutions of a regional, local or other nature, other bodies, the activities of which are governed by public law or by member states. In a wide definition of "public management", it is referred to public authorities and entities that are not organizationally intended, but perform delegated functions (Kravtsova \& Solonar, 2010). At the same time, "public authority" (or public authorities) should be understood as: any publiclaw body (including the state, regional and local public authorities, independent public enterprises) and any natural person in the exercise of their official authority (Hnydiuk, 2006).

However, V.K. Kolpakov draws attention to the fact that public management as a legal category has two dimensions: functional and organizational-structural. At the same time, the functional dimension involves the consideration of public management as an activity of relevant structural entities in the performance of functions aimed at the realization of public interest, and organizational-structural is a set of bodies formed for the implementation (realization) of public authority (2012). It should be noted that, from the structural dimension there is a quite widespread point of view that public management is an organically unified and functioning system of public administration, first of all, of executive authorities and local self-government bodies, their officials, as well as institutions and organizations, individual non-governmental entities that, in accordance with the law, perform public management functions to satisfy the public interest (Halunko, Dikhtiievskyi, Kuzmenko, Stetsenko et al., 2018). Supporters of this view are V.B. Averianov (2003), I.B. Koliushko, V.P. Tymoshchuk (2006), O.O. Hubanov (2018) and several other scientists.

The features that characterize the subject of public management are the following:

1) it is in a way a coherent and organized system of bodies, which is not hierarchically constructed, but must act in a coherent, purposeful manner, avoiding duplication of functions and unnecessary bureaucracy;

2) the subject is the state, the purpose of the activity of the subjects of public management is to ensure the public interest, that is, the interests of both the state and society as a whole, and not individual citizens or social groups;

3 ) the public management relies on authority, when performing public functions;

4) the activity of public management covers the whole society;

5) public management operates on the basis of a set of measures of influence: legal, political, economic, social; through the application of legal regulation methods: harmonization, persuasion, stimulation, coercion, etc.

Separately, one should dwell on such a functional attribute of the subject of public management as mandatory engagement with civil society institutions. Thus, the need to involve the society in public administration is conditioned by the National Strategy to Promote Civil Society Development in Ukraine for 2016-2020, the adoption of which provides for the creation of favorable conditions for the development of civil society, various forms of participatory democracy, establishment of effective interaction with public and local self-government authorities (Decree to Promote Civil Society Development in Ukraine, 2016).

At the same time, the forms of interaction of civil society institutions with the subjects of public administration differ depending on the rights granted to citizens. In general, this applies to: ensuring the ability of citizens to apply electronically to the subjects of public administration and the possibility of submitting an electronic petition (Law on Citizens' Appeals, 1996); conducting public consultations on the formulation and implementation ofpublicpolicy(Resolution OnEnsuring Public Participation in Public Policy Formation and Implementation, 2010); conducting public examination of the activity of public authorities, anti-corruption public examination of the activity of the subjects of public administration (Resolution on Approval of the Procedure for Promoting Public Expertise of the Activity of Executive Bodies, 2008); creation and functioning of public (expert) councils in the activity of public administration entities (Resolution On Amendments to the Resolution of the Cabinet of Ministers of Ukraine No. 996 dated 3 November 2010, 2019); ensuring that citizens can access public administration entities through telephone communications through designated contact centers, telephone hotlines, and the use of the Internet and electronic communications (Resolution On approval of the concept of establishing a National Contact Center, 2015), etc.

\section{Grading of subjects of public administration}

First of all, it should be noted that a unified approach to the grading of subjects of public administration has not been developed yet. However, in general, in the national legal science there are ways of allocating groups of subjects that carry out public administration, but without identifying the grounds for such a list.

Thus, the position of R.S. Melnyk and V.M. Bevzenko is quite interesting, which includ to the subjects of public administration the following components: bodies of state executive power, bodies of local self-government; their officials; other subjects in the exercise of their managerial functions on the basis of the legislation, in particular for the exercise of delegated powers; other subjects that are endowed with different administrative powers in terms of essence and scope (the Verkhovna Rada of Ukraine, the Accounting Chamber of Ukraine, the Ukrainian Parliament Commission for Human Rights, the President of Ukraine, etc.) (2014). 
However, in modern legal science there are several other quite common variants of the classification of the subjects of public administration, which are characterized by the different composition of the subjects. Some researchers take the position that the subjects of public management should be referred to as: bodies of state executive power, bodies of local selfgovernment; government bodies that do not belong to any of the branches of government (for example, the national commissions for the regulation of natural monopolies, the National Bank of Ukraine, the Security Service of Ukraine) (Karabin, 2015). At the same time, the legal literature prevails views on the separation among the subjects of public administration: bodies of state executive power, bodies of local self-government; other delegated subjects (Sukmanova, 2018).

At the same time, there is a quite interesting position of those scientists who refer to the subjects of public administration the following: public authorities of national importance; local public authorities; legal entities irrespective of ownership and organizational form or their separate subdivisions, which carry out public administration; non-governmental organizations acting as subjects of delegated authority and as a fullfledged subject of public administration (Bila-Tiunova, Neudodnikov, Danylenko, 2019).

Thus, the analysis of sustainable scientific achievements suggests that a unified approach to the grading of the subjects of public administration in scientific sources has not been formed yet. Therefore, it seems appropriate to use a combined approach whereby the separation of the subjects of public administration is made according to: the availability of powers of authority (entities empowered by such authority under the law and subjects empowered with such authority through delegation); the nature of the distribution of powers of authority (subjects operating at the national level and subjects operating at the local level); the type of public administration (subjects that engage in intrusive public administration; subjects that carry out security public administration; entities that carry out facilitative public administration); spheres of public administration (subjects of public administration in the field of national security; subjects of public administration in the field of health; subjects of public administration in the field of education; subjects providing public administration in the field of national security; subjects of public administration in the field of culture; subjects that carry out public administration in the use of information and telecommunications technologies; entities that carry out public administration in the field of ecology, etc.).

\section{Conclusions}

Summarizing the analysis of the institutional component of public administration and the changes experienced by the governing entities as a result of reformatting the concept of relations between the state and society in Ukraine, we come to the conclusion that in the conditions of building Ukraine as a democratic and legal state, all reform initiatives have systemic character. At the same time, only the use of a comprehensive approach will allow to look on the subjects of public administration as a coherent system and, in turn, make it possible to conduct not only their in-depth scientific analysis, but also effective reformation, which is of particular relevance beacuse of the current realities, given the globalization processes.

At the same time, given the peculiarities of the field of operation, it seems appropriate to define public administration as the activity of public authorities, which has a manifestation in the concerted influence on specific public relations by means of specific methods, tools, forms and aimed at securing public interests.

In addition, the study allowed to isolate features that characterize the system of subjects of public administration. After all, every subject of public administration should act in concert, purposefully, avoiding duplication of functions and unnecessary bureaucracy. At the same time, it seems urgent to establish mandatory interaction between public management and civil society institutions.

A well-balanced, effective and aimed at real improvement of social preconditions for establishing effective functioning of subjects of public administration may also become inclusion in the curricula of general, vocational, higher educational institutions courses and topics on subjective provision of public administration, as well as introduction of training in the system of higher and postgraduate education of specialists in the management of non-governmental organizations.

\section{References:}

Acevedo Torres Samuel Isaias, Barrutia Barreto Israel, Urquizzo Maggia, Jose Antonio, Venero Gibaja Roger (2019). The public administration and sense of welfare for progress. Religacion-revista de ciencias sociales y humanidades, vol. 4, pp. 178-185.

Bila-Tiunova, L., Bilous-Osin, T., Kozachuk, D., \& Vasylkivska, V. (2019). Participation of civil society in public administration: prospects for international experience implementation in Ukraine. Humanities \& Social Sciences Reviews, vol. 7, pp. 757-764. doi: https://doi.org/10.18510/hssr.2019.7594

Liubov Bila-Tiunova, Andrey Neugodnikov, Yuliia Danylenko (2019). The problems of public administration in the sphere of healthcare in Ukraine. International Journal of Applied Exercise P hysiology (IJAEP). Vol. 8, № 2.1, pp. 516-523. 
Nicolette van Gestel, Marlot Kuiper, Wiljan Hendrikx (2019). Changed Roles and Strategies of Professionals in the (co)Production of Public Services, Administrative science. URL: https://www.mdpi.com/2076-3387/9/3/59/htm Averianov, V.B. (2003). Reformuvannia ukrainskoho administratyvnoho prava: hruntovnyi pryvid dlia teoretychnoi dyskusii [Reform of the Ukrainian administrative law: a thorough ground for theoretical discussion]. Pravo Ukrainy, no. 5, pp. 117-122. (in Ukrainian)

Halunko, V., Dikhtiievskyi, P., Kuzmenko, O., Stetsenko, S. ta in. (2018). Administratyvne pravo Ukrainy. Povnyi kurs: pidruchnyk [Administrative law of Ukraine. Full course: textbook]. Kherson: Oldi-Plius. (in Ukrainian)

Bondarenko, K. V. (2018). Do pytannia rozmezhuvannia poniat "derzhavne upravlinnia" ta "publichne administruvannia" [On the question of distinction of the terms "state management" and "public administration"]. Derzhava ta rehiony, no. 3, pp. 80-84. (in Ukrainian)

Hnydiuk, N. (2006). Vyznachennia publichnoi administratsii v ACQUIS COMMUNAUTAIRE [Definition of the concept of public administration in ACQUIS COMMUNAUTAIRE]. Zakonodavstvo Ukrainy. Naukovo-praktychni komentari, no. 10, pp. 74-77. (in Ukrainian)

Kniaziev, V. M., \& Bakumenko, V. D. (2002). Derzhavne upravlinnia: slovnyk-dovidnyk [State management: a referential dictionary]. Kyiv: Vyd-vo UADU. (in Ukrainian)

Elistratov, A. I. (1917). Osnovnye nachala administrativnogo prava [Basic principles of administrative law. $2^{\text {nd }}$ edition]. Moskva. (in Russian)

Koliushko, I., \& Tymoshchuk, V. (2006). Efektyvna publichna administratsiia (docidnyk dlia ministriv) [Effective public administration (handbook for ministers) ]. Kyiv. (in Ukrainian)

Kodeks administratyvnoho sudochynstva Ukrainy: Zakon Ukrainy vid 06.07.2005 r. № 2747-IV [The Code of Administrative Proceedings of Ukraine: the Law of Ukraine No. 2747-IV dated July 06, 2005]. URL: https://zakon2.rada.gov.ua/laws/show/2747-15 (in Ukrainian)

Kravtsova, T. M., \& Solonar, A. V. (2010). Poniattia ta pryntsypy diialnosti publichnoi administratsii [Concept and Principles of Activity of Public Administration]. Forum prava, no. 4, pp. 522-525. (in Ukrainian)

Kolpakov, V. K., Kuzmenko, O. V., Pastukh, I. D., Sushchenko, V. D. ta in. (2012). Kurs administratyvnoho prava Ukrainy: pidruchnyk [Course of administrative law of Ukraine: textbook]. Kyiv: Yurinkom Inter. (in Ukrainian)

Melnyk, R. S., \& Bevzenko, V. M. (2014). Zahalne administratyvne pravo: Navchalnyi posibnyk [General administrative law: Educational guidance]. Kyiv: Vaite. (in Ukrainian)

Hubanov, O. (2018). Rol ta mistse tsentru adaptatsii derzhavnoi sluzhby do standartiv Yevropeiskoho Soiuzu u systemi subiektiv publichnoi administratsii Ukrainy [The role and place of the Centre for adaptation of the State Service to the standards of the European Union as the public administration of Ukraine]. Administratyvne pravo $i$ protses, no. 4, pp. 122-129. (in Ukrainian)

Karabin, T. O. (2015). Problemy vyznachennia subiektnoho skladu publichnoi administratsii [Problems of defonotopn of subject structure of public administration]. Prykarpatskyi yurydychnyi visnyk, no. 3, pp. 164-169. (in Ukrainian)

Pyrozhkova, Yu. V. (2017). Teoriia funktsii administratyvnoho prava: dys. ... d-ra yuryd. nauk [The theory of functions of administrative law: thesis of the Doctor of Juridical Sciences]. Zaporizhzhia. (in Ukrainian)

Pro zatverdzhennia Poriadku spryiannia provedenniu hromadskoi ekspertyzy diialnosti orhaniv vykonavchoi vlady: Postanova Kabinetu Ministriv Ukrainy vid 05.11.2011 r. № 976 [On Approval of the Procedure for Promoting Public Expertise of the Activity of Executive Bodies: Resolution of the Cabinet of Ministers of Ukraine No. 976 dated November 05, 2011]. (in Ukrainian)

Pro zabezpechennia uchasti hrmadskosti u formuvanni ta realizatsii derzhavnoi polityky: Postanova Kabinetu Ministriv Ukrainy vid 03.11.2010 r. № 996 [On providing for public participation in formulating and implementing public policy: Resolution of the Cabinet of Ministers of Ukraine No. 996 dated November 03, 2010]. (in Ukrainian) Pro zvernennia hromadian: Zakon Ukrainy vid 02.10.1996 r. № 393/96-BP [On Citizen’s Appeals: the Law of Ukraine No. 393/96-BP dated October 02, 1996]. (in Ukrainian)

Pro spryiannia rozvytku hromadskoho suspilstva v Ukraini: Ukaz Prezydenta Ukrainy vid 26.02.2016 r. № 68/2016 [On Promotion of Civil Society Development in Ukraine: Decree of the President of Ukraine No.68/2016 dated February 26, 2016]. (in Ukrainian)

Pro skhvalennia Kontseptsoo stvorennia Natsionalnoho kontaktnoho tsentru: Rozporiaszhennia Kabinetu Ministriv Ukrainy vid 02.12.2015 r. № 1269-p. [On approval of the concept of establishing a National Contact Center: Resolution of the Cabinet of Ministers of Ukraine No. 1269-p dated December 02, 2015]. (in Ukrainian)

Pro vnesennia zmin do postanovy Kabinetu Ministriv Ukrainy vid 3 lystopada 2010 r. № 996: Postabova Kabinetu Ministriv Ukrainy vid 24.04.2019 r. № 353 [On Amendments to the Resolution of the Cabinet of Ministers of Ukraine No. 996 dated November 3, 2010: Resolution of the Cabinet of Ministers of Ukraine No. 353 dated April 24, 2019]. (in Ukrainian)

Sukmanova, O. V. (2018). Poniattia ta systema subiektiv administruvannia okhiriny prav vlasnosti v Ukraini [Concept and system of subjects of public administration of property rights protection in Ukraine]. Naukovyi visnyk Mizhnarodnoho humanitarnoho universytetu, no. 33, pp. 64-67. (in Ukrainian)

Chernov, S. I. (2014). Tekst lektsii z dystsypliny "Publichne administruvannia" [The text of lectures on the discipline "Public administration"]. Kharkiv: KhNUMH. (in Ukrainian) 
Yakovliev, I. P. (2015). Publichne administruvannia u sferi derzhavnoi mytnoi spravy: terminolohichnyi poshuk [Public administration in the area of state customs: terminological search]. Yevropeiski perspektyvy, no. 6, pp. 119-125. (in Ukrainian)

Yakovliev, I. P. (2016). Formy i metody publichnoho administruvannia u derzhavnii mutnii spravi: dys. ... kand. yuryd. nauk [Forms and methods of public administration in the state customs: thesis of the Candidate of Juridical Sciences]. Odessa. (in Ukrainian)

Yarovska, V. (2016). Liudynotsentrystsla kontseptsiia administratyvno-pravovoi doktryny prava yak odeolohichna peredumova perehliadu zmistu metodiv administratyvnoho prava [Man-centered concept of administrative-legal doctrine as an ideological precondition for reviewing the content of administrative law methods]. Visegrad Journal on Human Rights, no. 6/3, pp. 160-168. (in Ukrainian) 